\title{
Using Water Balance to Analyse Water Availability for Irrigation with Upraising Surface Temperature (A case Study Pasar Baru Barrage in Cisadane Watershed)
}

\author{
Dwi Ariyani $^{1}$, Frederick Josep Putuhena ${ }^{2}$, Dharma Wira ${ }^{3}$ \\ ${ }^{1}$ Civil Engineering Department, Faculty of Engineering, Pancasila University, Jakarta \\ Selatan 126400, Indonesia \\ ${ }^{2}$ Civil Engineering Department, Faculty of Engineering, Pembangunan Jaya University, \\ Kota Tanggerang Selatan 15413, Indonesia \\ ${ }^{3}$ Bachelor School of Civil Engineering and Faculty of Engineering, Pancasila \\ University, Indonesia \\ dwi.ariyani@univpancasila.ac.id
}

Received 06-11-2019; accepted 17-02-2020

\begin{abstract}
This research determines water balance at Pasar Baru Barrage. and conducted to see the effect of rising temperatures on water requirements. Water requirement is calculated from irrigation, domestic and raw water, it is calculated by planning cropping pattern in one year. Evapotranspiration was calculated using Penmann Modification, Water availability calculated using FJ Mock, Maximum water availability value is $11.75 \mathrm{~m}^{3} / \mathrm{second}$. so that the water balance is obtained by surplus deficit water balance method. Air temperature in the Cisadane irrigation area is increasing from 1985 to 2018 . The average temperature increases by $0.74^{\circ} \mathrm{C}$, minimum air temperature increases by $0.8^{\circ} \mathrm{C}$ and the maximum increases by $0.2^{\circ} \mathrm{C}$, the average evapotranspiration value decreases by $0.15 \mathrm{~mm} / \mathrm{day}$, while the average water availability decreases from 1985 to 2018 at $1.8 \mathrm{~m}^{3} / \mathrm{second}$. Amount of water needed for irrigation was 5.57 liters/second/ha. it can see that the water balance has a surplus every year, the water balance deficit only occurred in July 2015 of $0.3 \mathrm{~m}^{3} / \mathrm{sec}$. The largest water balance occurred in March 2014 amounting to $656.97 \mathrm{~m}^{3} / \mathrm{sec}$. The results of this study can be used as a reference in planning and developing integrated water resources buildings especially in the Cisadane watershed and the Ciliwung-Cisadane river basin in general.
\end{abstract}

Keywords: water balance, Ciliwung-Cisadane watershed, water requirement, irrigation, water availability

\section{Introduction}

The increase in the earth's surface temperature is the real thing that must be ready to be faced by humanity on earth, now scientists continue to find out the effects of changes in surface temperature, based on the 100-year trend (1906-2005) there is an increase in the average surface temperature of the earth $0.740 \mathrm{C}+0.180 \mathrm{C}$ [1] According to an ongoing temperature analysis conducted by scientists at NASA's Goddard Institute for Space Studies (GISS), Since 1880 the average global temperature on Earth has increased by about $0.8^{\circ}$ Celsius [2], updated reports every month about changes in the earth's surface temperature can be seen on the GHCN website, GHCN analyses more than 7000 meteorology

Cite this as: Ariyani, D., Putuhena, F., \& Wira, D. (2020). Using Water Balance to Analyse Water Availability for Irrigation with Upraising Surface Temperature (A case Study Pasar Baru Barrage in Cisadane Watershed). Civil and Environmental Science Journal, 3(1), pp.1-9. doi: https://doi.org/10.21776/ub.civense.2020.00301.1 
stations in the world, to find out changes in surface temperature in more detail. There are 4.7 million station months of temperature data in GHCN, starting in 1701 and continuing to the present [3] according to GHCN highest temperature change it is happen in north and south earth hemisphere, while in the area tropical temperature change is not until 10C. Except Afrika Continent, even though it's located in the equator the temperature change it's extremely reach until $2.5^{\circ} \mathrm{C}$ [4], in the north pole area temperature exchange until to $3.8^{\circ} \mathrm{C}[5,6]$

Research on the Donau River, which is the longest river in Europe, states that Climate change affects all elements of the water balance: precipitation, evapotranspiration and runoff. Decreasing annual precipitation by $55 \mathrm{~mm}$ and increasing annual evaporation by $47 \mathrm{~mm}$ leads to a decrease in annual availability by $102 \mathrm{~mm}$ in the upper Danube river basin, the highest impact found in the northern edge of the Alps, where water availability decreases by up to $400 \mathrm{~mm}$ [7] Hydrological Cycle is strongly influenced by the earth's surface temperature and radiation balance, high surface temperatures cause the hydrological cycle intensity, resulting in higher rates of evaporation and increasing liquid precipitation, this causes a shift from run off distribution, soil moisture, ground water, and evaporation. India predicts that without climate change demand for irrigation water will increase by around $3.5-5 \%$ in $2025,73 \%$ of water use in India is for irrigation, in Gujarat it is predicted to fall -6 to $-8 \%$, while in north-western India rainfall rises around 10\% from normal, without doing good water management, it is likely that India will have a water deficit [8]. Furthermore, the effect of change evaporation due to change in surface temperature is influenced by geographical location, and irrigation designation. This study aims to determine the effect of change in surface temperature over the past 30 years on water requirement by taking cases in Karawang, West Java, in this area the land is quite large, so further research is needed condition of the water balance.

\section{Material and Methods}

\subsection{Data Used}

Data used for the research is Temperature, rainfall data, relative humidity, wind speed, solar, and etc. Climatology data was obtained from climatology station from 1985 to 2018. The research located in Koang Jaya Village, Karawaci, Tanggerang (Figure 1).

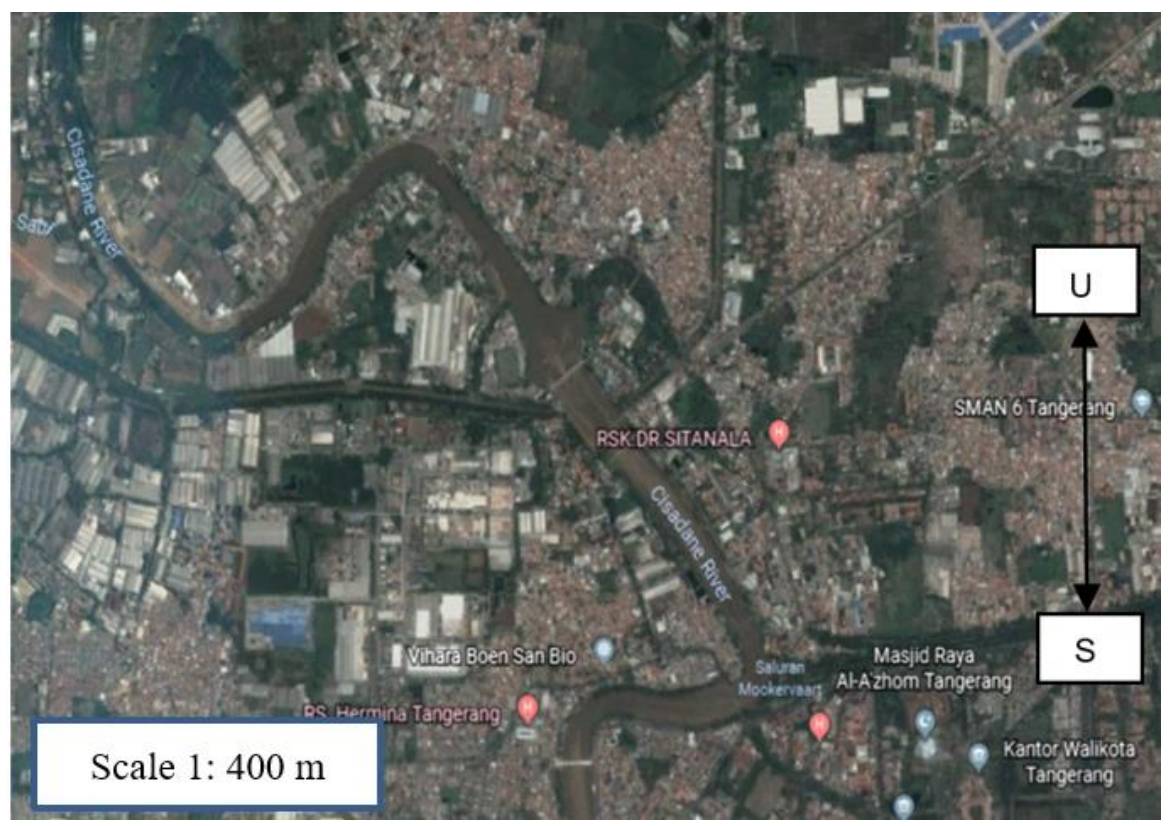

Figure 1. Area Location Pasar Baru Barrage

The Cisadane Irrigation Area (DI) covers the Tanggerang Regency and a small part of the Tanggerang City area. The water source in Cisadane comes from the Cisadane River trough the Pasar 
Baru Barrage located in the Tanggerang sub-district, Tanggerang City. The area of DI Cisadane in 2004 was $22.269 \mathrm{Ha}$ and then reduced to $22.053 \mathrm{Ha}$ in 2007, and in 1988 an area of $38.634 \mathrm{Ha}$. There has been a change of function in an area of $16.581 \mathrm{Ha}$ which is used for settlements, industry and SoekarnoHatta Airport.

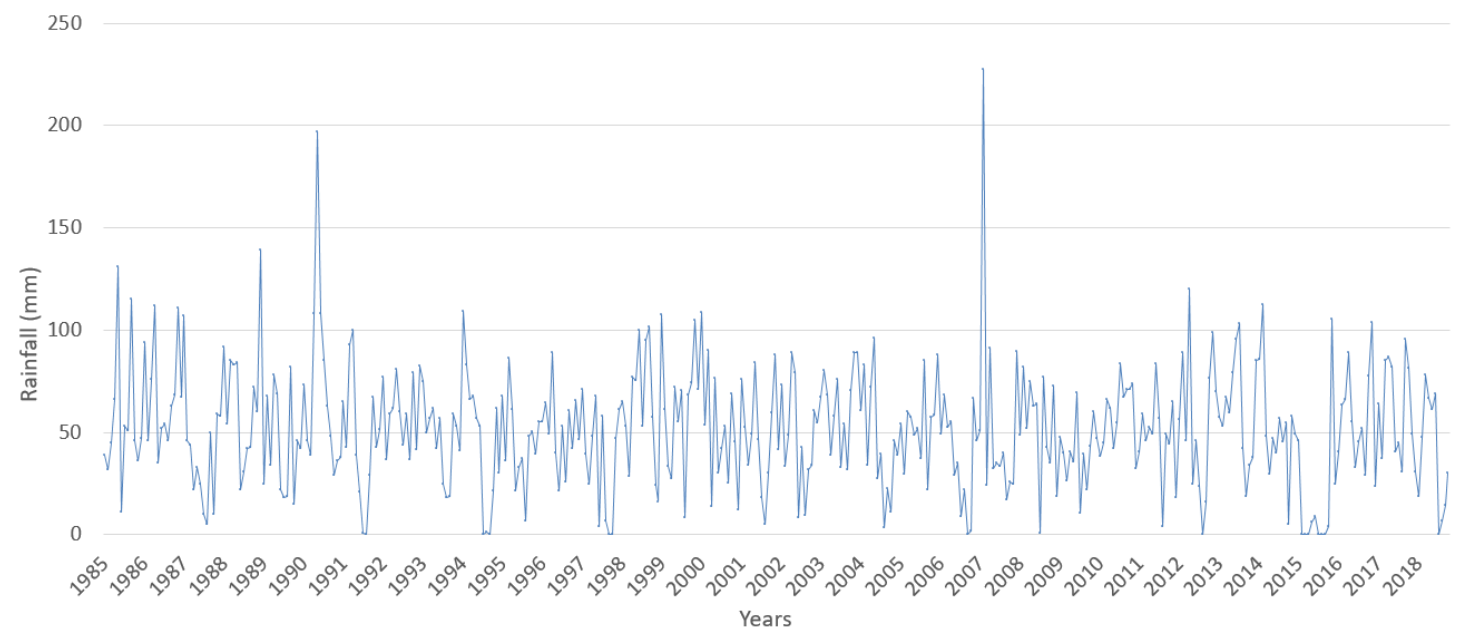

Figure 2. Monthly Rainfall Graph in Budiharto Station

From the monthly rainfall graph every year in Pasar Baru Barage it is known that the maximum monthly rainfall occurred in February 2007 amounting to $227.5 \mathrm{~mm}$ (Figure 2). Therefore, it can be seen that rainfall is fluctuating. Temperature data from the climatology station Budiharto In Tangerang, in the form of data of maximum, minimum and average temperature for 33 years, from 1985 to 2018. The maximum air temperature occurred in October 2002 at $37.8^{\circ} \mathrm{C}$

\subsection{Methods}

For this research used the temperature and rainfall data from BMKG, temperature data is used to analyzed evapotranspiration with penman modification method. The rainfall data is for calculate water availability with mock method. Using mann kendall to know temperature rise [8]. Temperature is related to water availability and water demand. To calculate water requirement for irrigation, must be known in advance the value of evapotranspiration and effective rainfall. Evapotranspiration is calculated based on

Climatological data from Budiharto station using modified penman method, while reliable rainfall is calculated based on rainfall data using the Basic year method, the effective rainfall value for rice plant is $70 \%$ from the reliable rainfall. Calculation of irrigation water requirement in rice fields is calculated according to the formula:

$$
N F R=E T c+P+W L R-R e
$$

Where; NFR is Netto Field Water Requirement ( $\mathrm{mm} /$ day), ETc is plant evaporation $(\mathrm{mm} /$ day), P is Percolation ( $\mathrm{mm} /$ day) and WLR is Replacement of water layer for flooding $(\mathrm{mm} /$ day), while Re is effective rainfall. The WLR value for replacing the water layer is taken as $1,1 \mathrm{~mm} /$ day, the percolation value based on the type of soil is taken $3 \mathrm{~mm}$.

Water balance calculate based on surplus deficit water balance, is mean the water available reduced by water requirement. In this study the water balance based on the mainstay discharge in the river calculated from rainfall data, Compare to discharge from measurement in Pasar Baru Barrage. The available discharge data at Pasar Baru Barrage is obtained for five years, in year 2013 to 2017 from the Cidurian-Cisadane Water Resources Management (BPSDA) 


\section{Result and Discussion}

\section{1. Analysis Result of Air Temperature}

Each To analyze air temperature and rainfall data using the Mann-Kendall trend test [8] [9] [10] [11]. Assumed that $\mathrm{H} 0$ is no trend and $\mathrm{Ha}$ there is trend. If p-value greater than alpha is mean $\mathrm{H} 0$ is rejected, and conversely.

From the results of the trend line analysis at the average air temperature, it can be seen that the pvalue is smaller than the significant alpha level so that $\mathrm{H} 0$ is rejected and $\mathrm{Ha}$ is accepted. If $\mathrm{Ha}$ is accepted, it means that there is a trend of rising temperatures on average in the period 1985 to 2018. During the 33 years the average temperature increase occurred at $0.74^{\circ} \mathrm{C}$. the graph of the average temperature rise trend can be seen in Figure 3.

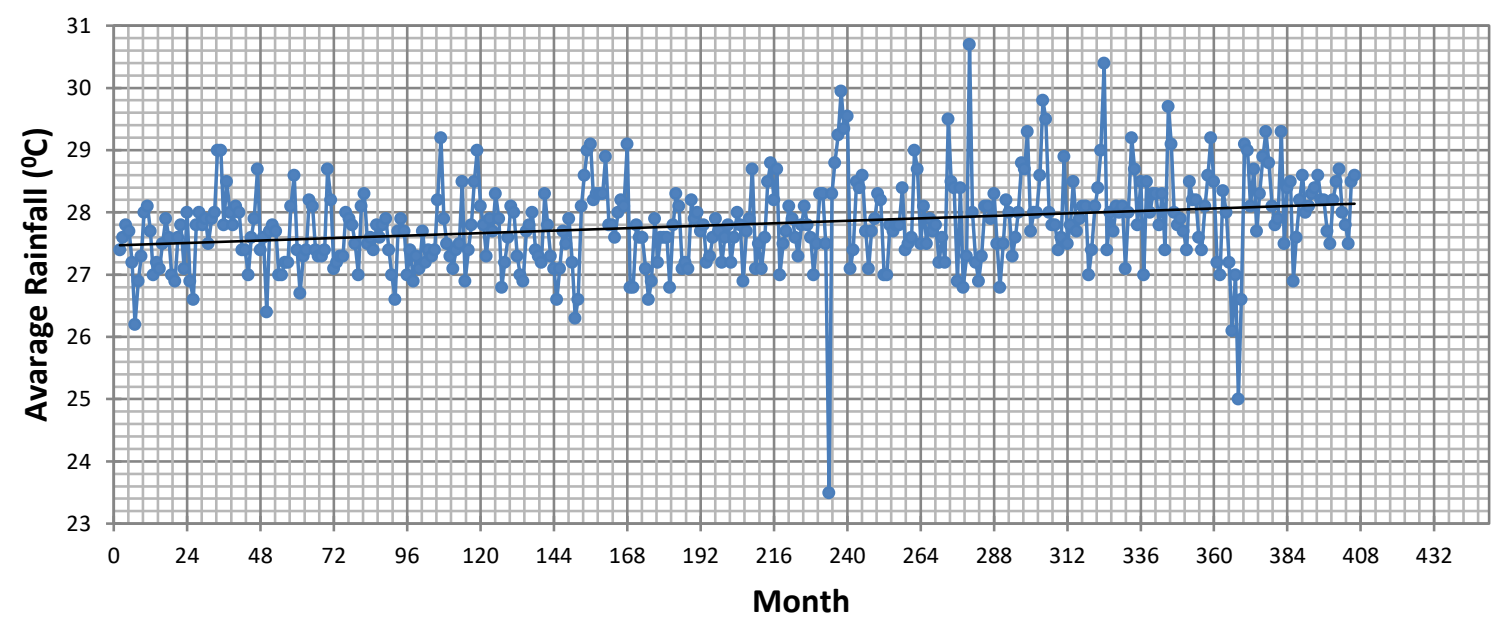

Figure 3. Average air temperature graph from $1985-2018$

At the minimum air temperature of the Mann-Kendall trend test it is known that $p$-Value is smaller than the significant alpha level, it means that the alternative hypothesis Ha is accept. The minimum increase in air temperature for 33 years is from 1985 to 2018 of $0,8^{\circ} \mathrm{C}$. The minimum trend of rising air temperature graph can be seen in Figure 4.

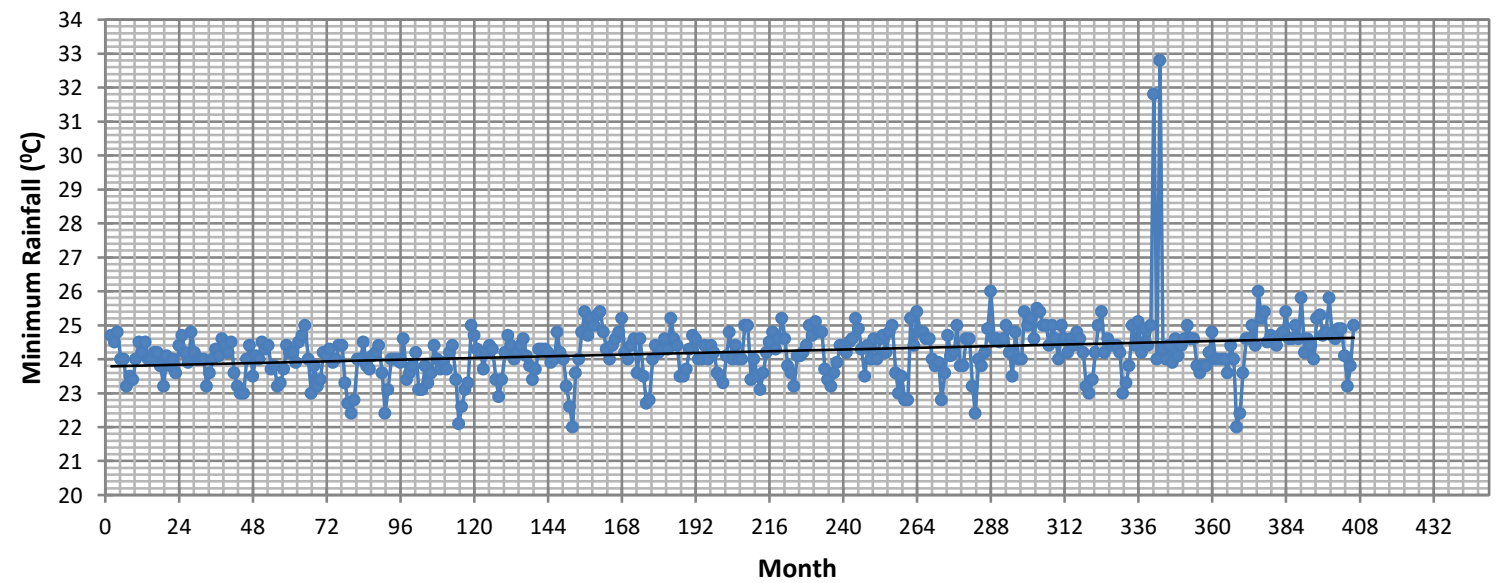

Figure 4. Minimum air temperature graph from- 2018 
The results of the analysis of the maximum air temperature trendline using the Mann-Kendall Trend test. As the computed p-value is lower than significance alpha level, one should reject the null hypothesis $\mathrm{HO}$, and accept the alternative hypothesis Ha. The risk to reject the null hypothesis H0 while it is true is lower than 1,17\%. From Figure 5, it can be seen that the maximum air temperature has increased by $0,2^{\circ} \mathrm{C}$ for the last 33 years, from 1985 to 2018 .

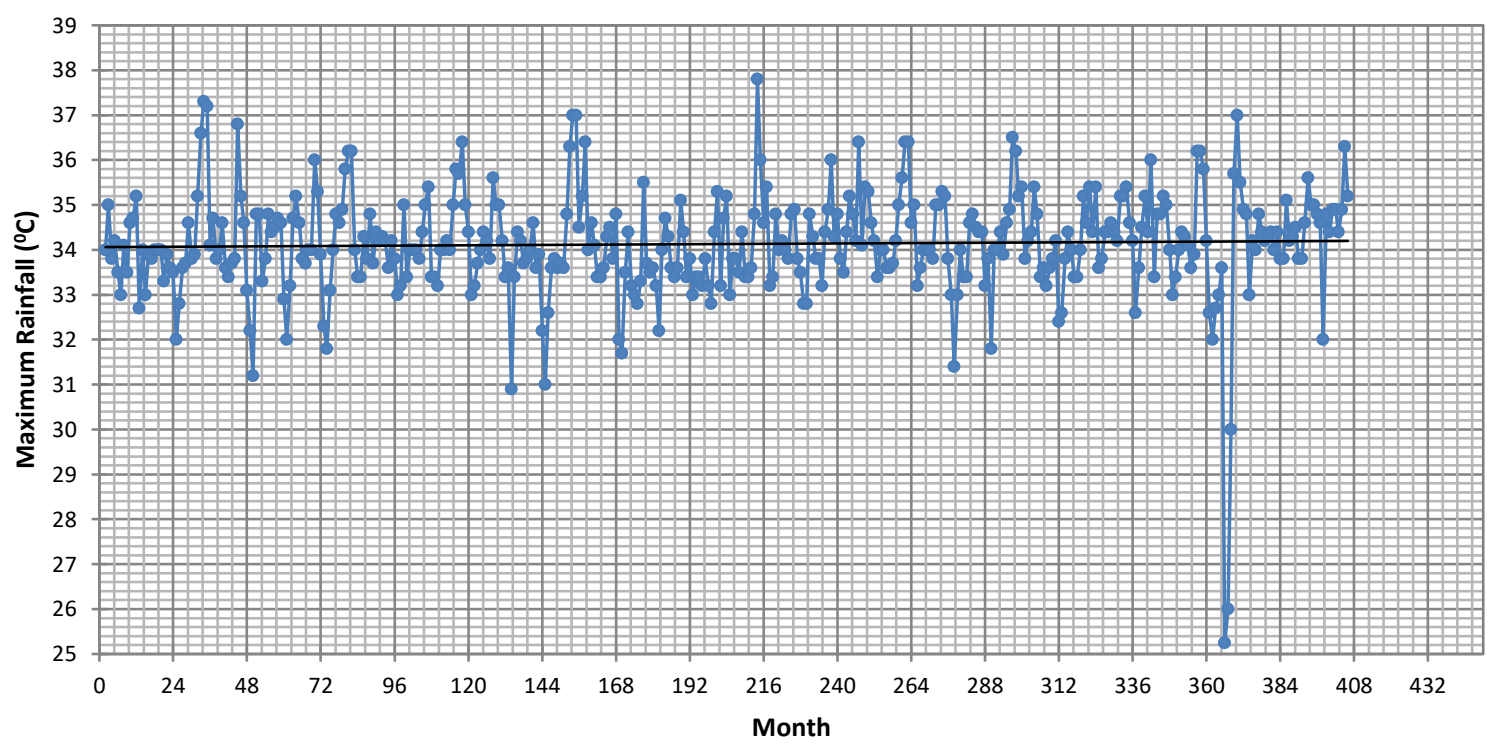

Figure 5. Maximum Air Temperature Graph from 1985 - 2018

\section{2. Evapotranspiration Calculation Result}

The evapotranspiration value is calculated based on data on air temperature, relative humidity, solar, wind speed from climatology station, for 33 years, from 1985 to 2018. By using the modified Penmann method it is known that the evapotranspiration value for the last 33 years can be seen in Figure 6 . The graph below.

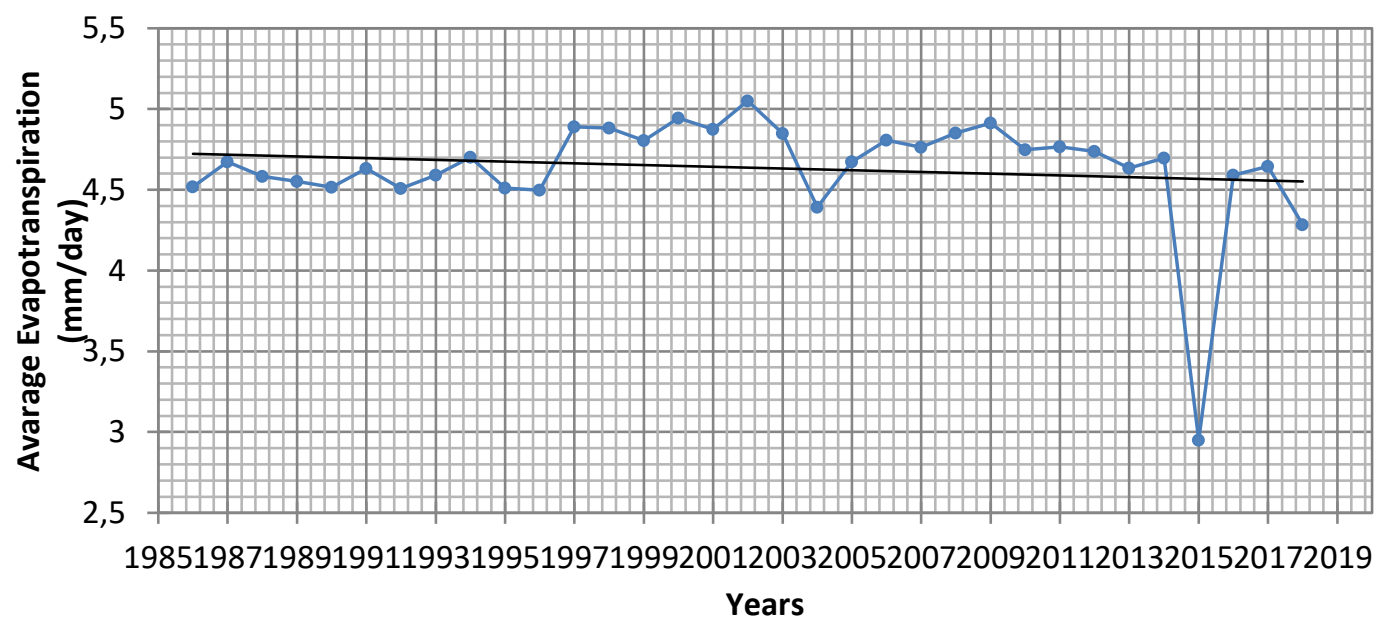

Figure 6. Evapotranspiration chart from $1985-2018$

From the Mann-Kendall trend test result. As the computed p-value is greater than significance level alpha, one cannot reject the null hypothesis $\mathrm{H} 0$. The risk to reject the null hypothesis $\mathrm{H} 0$ while it is true 
is $84.18 \%$. Furthermore, there is no trend in evapotranspiration analysis. The evapotranspiration value has decreased for 33 years, which is equal to $0.15 \mathrm{~mm} /$ day.

\section{3. Irrigation Water Requirement Calculation Result}

Irrigation water needs are calculated based on the planned cropping pattern. In this study the pattern of planting that is used Palawija-Padi-Padi, within one year of planting two crops of rice and one. Calculation resulting from the value of irrigation water needs of 1985 to 2018 units per month with a liter/second/ha, multiplied by the total area irrigated by the weir irrigation New Market, a score needs water in paddy fields $\left(\mathrm{m}^{3} / \mathrm{s}\right)$. Graph value of irrigation water requirement can be seen in Figure 7 below.

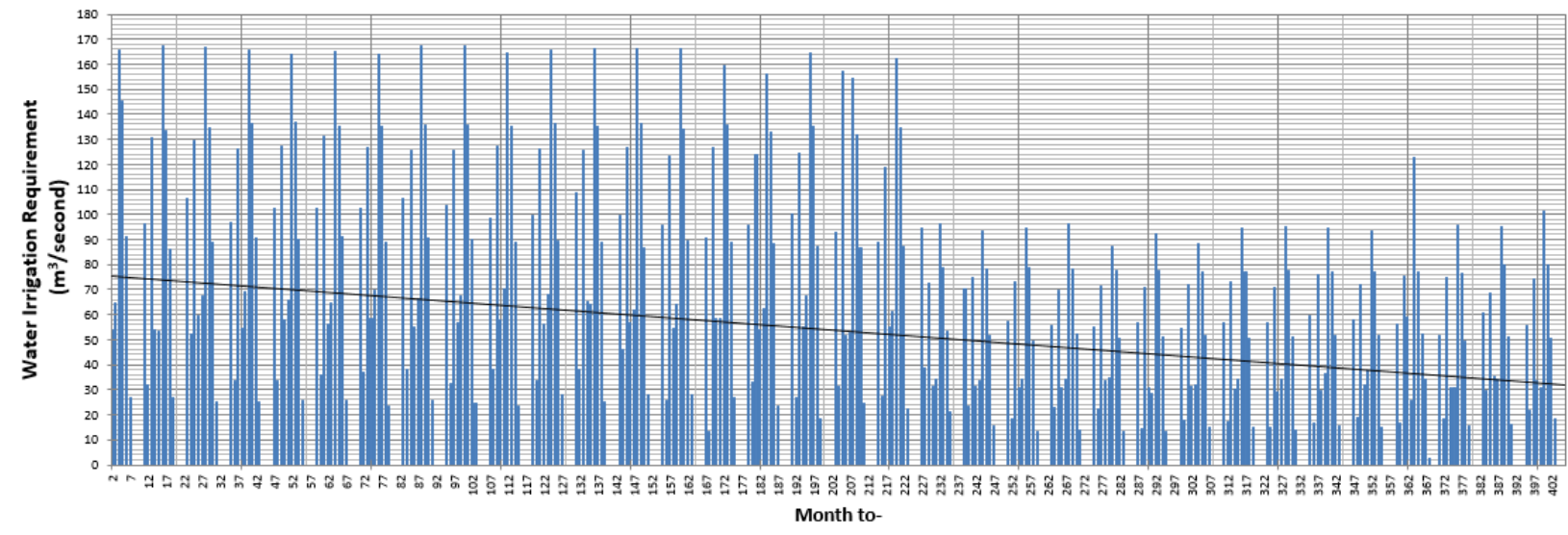

Figure 7. Irrigation Water Requirement Graph 1985 - 2018

From the graph in figure 7 above it can be seen that the amount of its water demand decreased from 1985 to 2018 , this was due to the degradation of agricultural land to settlements, industry and SoekarnoHatta Airport. From 1988 to 2007, degradation of agricultural land of 16.581 ha which causes a decrease in irrigation water demand by $44 \mathrm{~m}^{3} / \mathrm{s}$ from 1985 to 2018 .

\section{4. Water Availability Calculation Result}

Calculation of water availability is calculated based on the rainfall data for 33 years at the station Budiharto, using the FJ Mock method to get a debit mainstay of every month. Mainstay discharge calculation results can be seen in Figure 8 below.

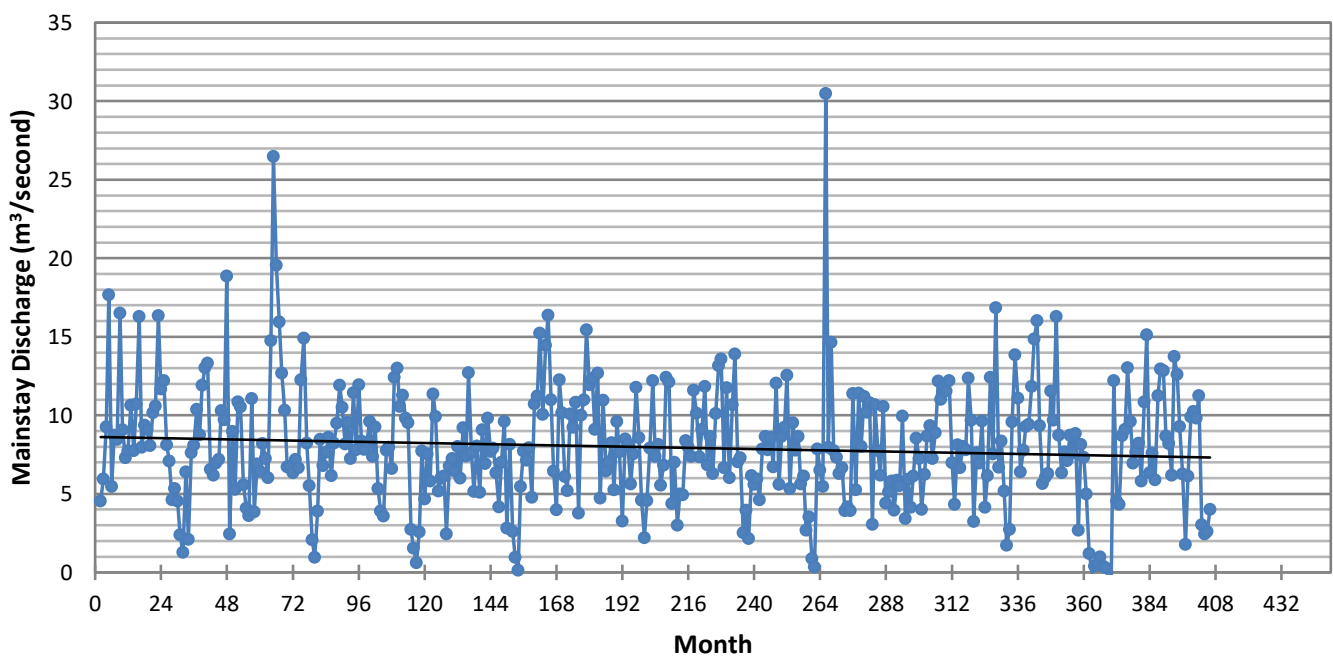

Figure 8. Mainstay discharge from $1985-2018$ 
From the graph above it can be seen that there was a decrease in water availability of $1.8 \mathrm{~m}^{3} / \mathrm{sec}$ from 1985 to 2018.

\section{5. Water Balance Calculation Result}

The results of the water balance calculation based debit available in Cisadane can be seen in Figure 9 below.

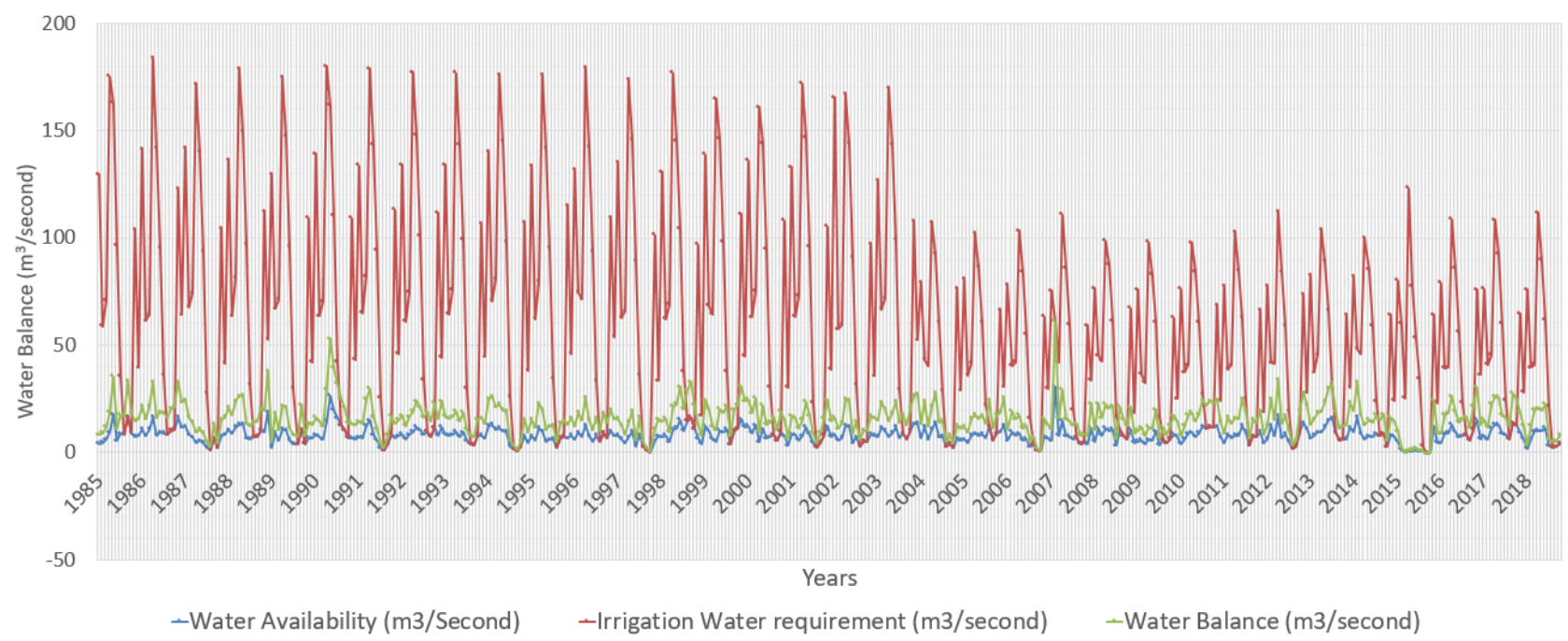

Figure 9. Water Balance from water avaibility Cisadane River and water irrigation in1985 - 2018

From the graph of the water balance in the figure 8 above it can be seen that the availability of river water Cisadane cannot meet the water needs of irrigation, water irrigation (red line) is greater than availability (blue line) so that the water balance (green line) in deficit each year. The water balance deficit occurred in April 1987 amounted to $162,32 \mathrm{~m}^{3} / \mathrm{sec}$.

From the calculation of the water balance in the Pasar baru Barrage based on data flow available at the weir for 5 years is 2013 to 2017 is known that the availability of water is sufficient irrigation water Cisadane from 2013 to 2017 there was a surplus of water balance, the bigest water balance excess occur in March 2014 amounted to $656.97 \mathrm{~m}^{3} /$ second. And the deficit in July 2015 was $0.30 \mathrm{~m}^{3} /$ second. So with the Pasar Baru Barrage there is sufficient water in the Cisadane irrigation area.

The water balance chart from 2013 to 2017 in Pasar Baru Barrage can be seen in figure 10 and 11 below.

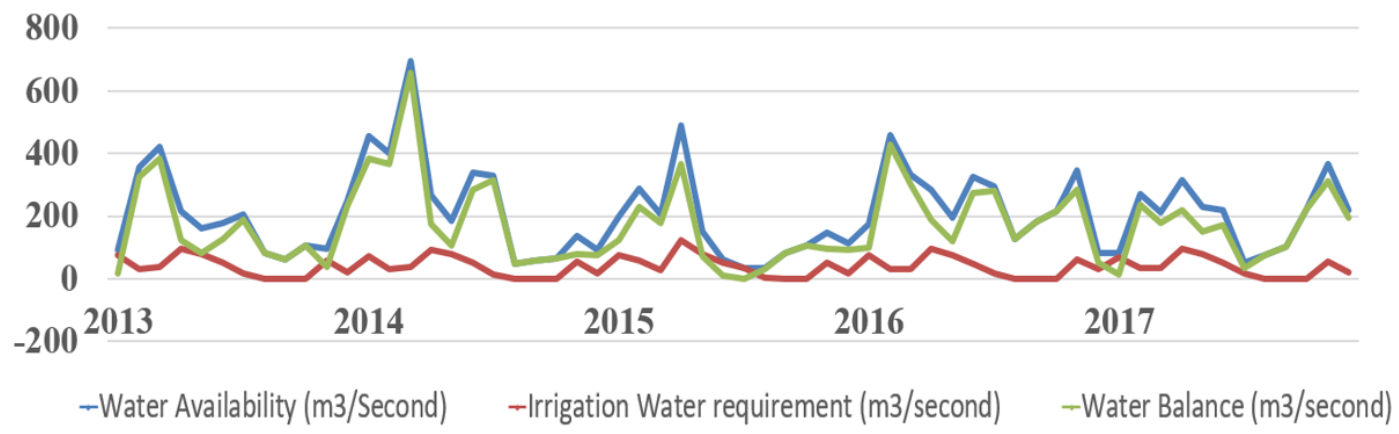

Figure 10. Water Balance from water availability Bendung Pasar Baru and water irrigation in 2013 2017 


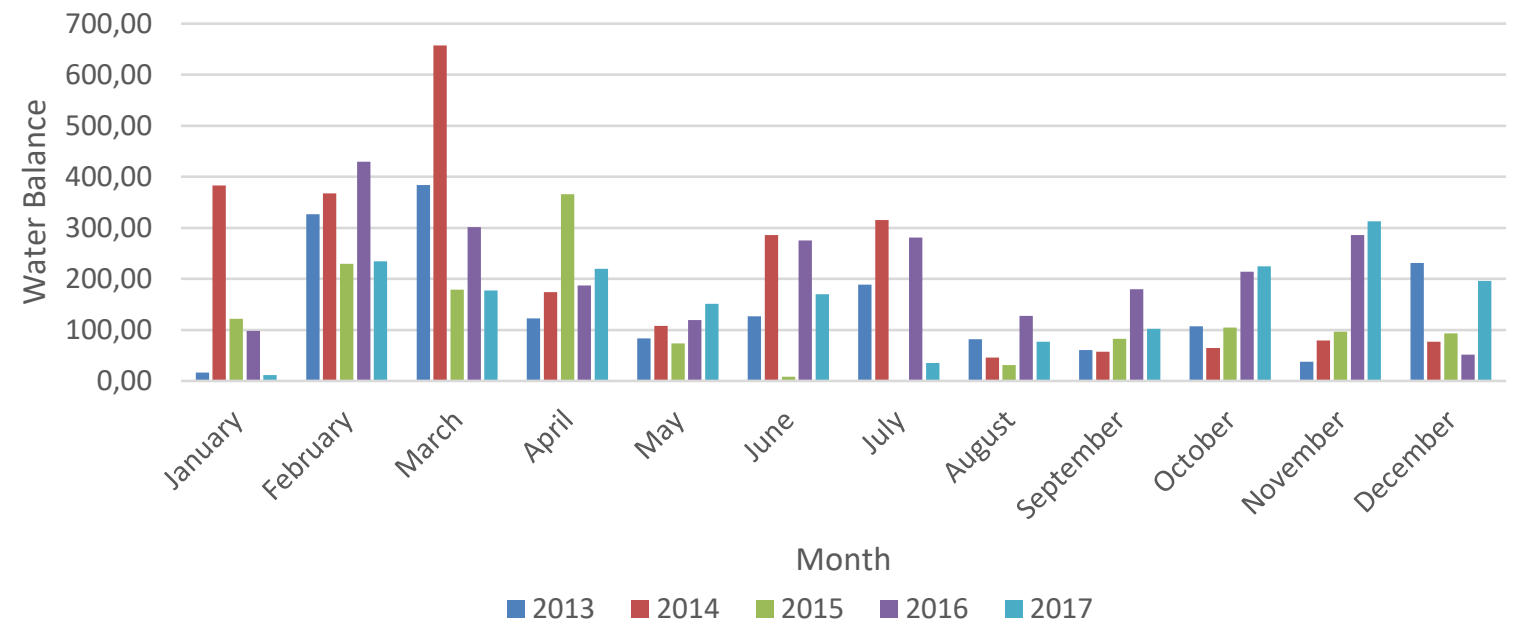

Figure 11. Water Balance from water avaibility Pasar Baru Barrage and water demand tahun 2013 2018 per month

\section{Conclusions}

The research was conducted to determine the climatological changes, both air temperature and rainfall that occurred in the Cisadane watershed. It can be seen that rainfall has fluctuated in the last 33 years, the average temperature has increased by $0.74^{\circ} \mathrm{C}$, the maximum has increased by $0.2^{\circ} \mathrm{C}$ and the minimum has increased by $0.8^{\circ} \mathrm{C}$ for the last 33 years. Although the temperature of the last 33 years has increased, the value of evapotraspiration has decreased by $0.15 \mathrm{~mm} /$ day. The value of water requirement for irrigation has decreased this is due to the conversion of irrigation land into settlements, industry and others. Although the value of irrigation water requirement is decreasing from year to year but the availability of water in the Cisadane river cannot sufficient water requirement, there is always deficit every year, so Pasar Baru Barrage are needed to sufficient water requirement. Based on data availability of Pasar Baru barrage discharge for 5 years from 2013 to 2017, the water balance deficit occurred in July 2015 of $0.3 \mathrm{~m}^{3} / \mathrm{sec}$, and the largest surplus occurred in March $2014 \mathrm{of} 656.97 \mathrm{~m}^{3} / \mathrm{sec}$.

\section{Acknowledgements}

Thanks to various parties who have contributed and supported the implementation of this research process, especially to the LPPM Faculty of Engineering, Pancasila University for the funds that have been given for this research

\section{References}

[1] IPCC., 2007 Intergovernmental Panel on Climate Change, IPCC Fourth Assessment Report : Climate Change

[2] NASA., 2018. World Global Temperature, article site: https://earthobservatory.nasa.gov/WorldOfChange/DecadalTemp, access on Oct 2018.

[3] Peterson, Thomas C., Vose, Russel S (1997) An Overview of the Global Historical Climatology Network Temperature Database, Bulletin of the American Meteorological Society, Vol. 78, No. 12.

[4] Christy, J. R., W. B. Norris, and R. T. McNider.,2009. Surface temperature variations in East Africa and possible causes, J. Clim., 22, 3342-3356, doi:10.1175/2008JCLI2726.1. 
[5] NOAA., 2018. National Centers for Environmental Information, State of the Climate: Global Climate Report for January 2018, published online February 2018, retrieved on October 29, 2018 from https://www.ncdc.noaa.gov/sotc/global/201801.

[6] Karl, T. R., C. N. Williams, P. J. Young, and W. M. Wendland (1986), Model to estimate the time of observation bias associated with monthly mean maximum, minimum and mean temperatures for the United States, J. Clim. Appl. Meteorol., 25, 145-160, doi:10.1175/15200450(1986)025<0145:AMTETT>2.0.CO;2.

[7] Zabel F (2016) Impact of Climate Change on Water Availability. In: Mauser W., Prasch M. (eds) Regional Assessment of Global Change Impacts. Springer, Cham Pathak, Surendra,. et all, Climate change and water availability in Indian agriculture: Impacts and adaptation, Indian Journal of Agricultural Sciences, 84(6):671-679

[8] Karmeshu, N (2012). Trend detection in annual temperature \& precipitation using the Mann Kendall test-a case study to assess climate change on select states in the northeastern United States (Tesis). University of Pennsylvania, Pennsylvania, USA. Diperoleh dari http://repository.upenn.edu/cgi/view content. cgi?article=1045\&context=mes_capstones

[9] Ahmad, Ijaz, Deshan Tang, Tianfang Wang, Mei Wang, and Bakhtawar Wagan (2015). "Precipitation Trends over Time Using Mann-Kendall and Spearman's Rho Tests in Swat River Basin , Pakistan."

[10] Blain, Gabriel Constantino., 2013. "Acta Scientiarum The Mann-Kendall Test: The Need to Consider the Interaction between Serial Correlation and Trend." (iid):393-402.

[11] Journal, International (2014). "Trend Analysis of Hydro-Meteorological Variables Using The Mann-Kendall Trend Test : Aplication to the Niger River. 100-110.

[12] Mondal, Arun, Sananda Kundu, and Anirban Mukhopadhyay (2012). "Rainfall Trend Analysis by Mann-Kendall Test: A Case Study of North-Eastern Part of Cuttack District, Orissa Rainfall Trend Analysis by Mann-Kendall Test 